\title{
Urgensi Fotografi Monokromatik Hitam Putih Dalam Dunia Fotografi Modern
}

\author{
Michel Sutedja S.Sn., M.Ds. ${ }^{1}$, Fairuz Athoriq ${ }^{2}$ \\ ${ }^{1}$ Program Studi Desain Komunikasi Visual, Universitas Pembangunan Jaya \\ Tangerang Selatan, Banten 15413, Indonesia \\ ${ }^{2}$ Program Studi Desain Komunikasi Visual, Universitas Pembangunan Jaya \\ Tangerang Selatan, Banten 15413, Indonesia \\ Email korespondensi: michel.sutedja@upj.ac.id
}

Received 29 December 2020, Revised 21 April 2021, Accepted 11 May 2021

\begin{abstract}
Over the last two decades, photographing in color is a very common thing in the world of photography. Even beginners in the world of photography can be said to have abandoned black and white photos. Most of the oldest people in this modern era know color photography from the first time they know the world of photography itself, in contrast to those who were born in the early days where the world of photography only knows black and white. The visualization of black and white monochoromatic photography is capturing and speaking through colorless photos by relying on the visualization of depth and contrast in strong and clear. Prior to the 20th century, photography without color or black and white was a normal and normal way of recording images, whereas in the modern world like today most people were more familiar with color photography. However, some people still argue that black and white monochoromatic photographs are important for documentation, art, and journalism. Monochromatic black and white photos create a unique impression that cannot be seen in color photos. The comoposition, depth of field and level of contrast in a black and white monochromatic photo can present a different scene from the same photo displayed in a color photo and often do not require further processing with image processing software because they can display their own beauty and uniqueness. The visualization of black and white monochromatic photography is capturing and speaking through photos without the presence of color by relying on the visualization of depth and contrast in strong and clear.
\end{abstract}

Keywords: Photography, Monochromatic, Journalism, Black and White.

\begin{abstract}
Abstrak - Lebih dari dua dekade terakhir memotret dalam format berwarna adalah hal yang sangat jamak dalam dunia fotografi. Pemula dalam dunia fotografi pun dapat dikatakan sudah meninggalkan foto hitam putih. Kebanyakan orang tertuama di jaman modern ini mengenal fotografi berwarna sejak pertama kali mengenal dunia fotografi itu sendiri, berbeda dengan mereka yang terlahir pada masa awal dimana dunia fotografi hanya mengenal hitam putih. Visualilsasi dari fotografi monokoromatik hitam putih adalah menangkap dan berbicara melalui foto tanpa warna dengan mengandalkan visualisasi kedalaman dan kontras secara kuat dan jernih. Walaupun demikian, sebagian orang tetap berpendapat bahwa foto monokoromatik hitam putih penting untuk dokumentasi, seni, dan jurnalisme. Foto monokromatik hitam putih menciptakan impresi yang unik dan hal itu tidak dapat dilihat dalam foto berwarna. Komoposisi, kedalaman ruang dan tingkat kekontrasan dalam foto monokromatik hitam putih dapat menampilkan sebuah pemandangan yang berbeda dari foto yang sama yang ditampilkan dalam fotmat berwarna dan sering kali tidak memerlukan pengolahan lebih lanjut dengan perangkat lunak pengolah gambar karena sudah dapat menampilkan keindahan dan keunikannya sendiri. Visualisasi dari fotografi monokromatik hitam putih adalah menangkap dan berbicara melalui foto tanpa kehadiran warna dengan mengandalkan visualisasi kedalaman dan kontras secara kuat dan jernih.

Kata Kunci: Fotografi, Monokromatik, Jurnalisme, Hitam Putih
\end{abstract}

\section{PENDAHULUAN}

Dalam dunia modern masa kini penggunaan foto dalam dunia desain grafis adalah hal yang umum dimana foto yang biasanya digunakan adlah foto berwarna. Jarang kita temui penggunaan foto monokromatik hitam putih dalam dunia desain grafis. Walaupun demikian, orang sering kali dikejutkan oleh kekuatan visual yang dihasilkan dari foto monokromatik hitam putih.

Penggunaan foto dengan format berwarna atau monokromatik hitam putih bukanlah suatu pilihan melainkan suatu alasan yang kuat. Tidak semua foto akan dapat dipresepsi dengan baik sesuai dengan yang diinginkan baik dalam format berwarna 
mauppun dalam format monokromatik hitam putih. Terdapat beberapa alasan dalam menentukan pilihan penggunaan suatu format dalam dunia fotografi. Alasan yang paling sering dijadikan alasan adalah mood (suasana). Tidak semua foto dapat dipersepsi dengan baik jika ditampilkan dalam format hitam putih, dan tidak semua foto dapat dipersepsi dengan baik jika ditampilkan dalam format berwarna. Jika sesuai dengn estetikanya, suasana yang terbangun dari sebuah foto dapat menjadi lebih kuat. Suasana yang kuat juga hanya dapat ditampilkan lewat objek momen dan konten yang sesuai dari foto tersebut. Alasan pertama adalah kesederhanaan. Seorang fotografer yang menginginkan penikmat foto untuk langsung fokus terhadap pesan yang ingin disampaikan tanpa adanya gangguan dari banyaknya warna-warna yang ditampilkan. Alasan kedua adalah karena hasil foto yang memang miskin akan warna. Sebuah foto yang tampil dengan warna-warna yang kurang menarik dapat dikonversi kedalam format hitam putih untuk dapat memberi penekanan pada momen dan/atau konten dari foto itu sendiri.

Dalam penelitian ini peneliti mencoba untuk memahami dan menjelaskan kapan foto monokromatik hitam putih dapat digunakan dan halhal apa saja yang harus diperhatikan pebuatan dan penggunaannya dalam dunia modern, terutama dalam hubungannya dengan persepsi yang akan ditimbulkan dan pesan yang ingin disampaikan.

\section{METODE PENELITIAN}

Metode penelitian yang digunakan dalam penelitian ini adalah metode penelitian kualitatif yang deskriptif, yaitu penelitian yang menjabarkan fenomena fotografi monokrom hitam putih. Menurut Kirk dan Miller (1986:9) bahwa penelitian kualitatif adalah tradisi tertentu dalam ilmu sosial yang secara mendasar bergantung pada pengamatan pada manusia dalam kawasannya sendiri dan berhubungan dengan orang-orang tersebut dalam bahasa dan peristilahannya. Dalam penjabarannya menggunakan landasan teori sebagai penuntun dalam melakukan penelitian agar sesuai dengan fakta yang ada di lapangan. Dalam penelitian ini peneliti menggunakan pendekatan grounded theory, bertolak dari hasil observasi yang merupakan pengalaman dengan menggunakan fenomenologi sehingga lebih merujuk kepada esensi dari objek untuk mereduksi subjektifitas penulis dan pengalaman orang lain, baik dalam bentuk tulisan maupun ucapan. Penulis menggunakan teori yang ada sebagai bahan penjelas dan berakhir dengan suatu kesimpulan. Strategi atau pendekatan grounded theory digunakan juga dengan pertimbangan keleluasaan dalam meneliti, yaitu secara induktif, sehingga data yang terhimpun dapat diperkaya sebagai solusi pengkajian.

Terdapat tiga metode pengumpulan data yang umum digunakan dalam penelitian, yaitu wawancara, observasi dan kuisioner. Pada penelitian ini penulis menggunakan dua metode yaitu wawancara dan observasi. Wawancara adalah suatu bentuk pertukaran informasi antara pewawancara dan yang diwawancara. Dalam melakukan wawancara penulis menyiapkan perencanaan dan menetapkan tujuan khusus dimana wawancara dilakukan dengan pertanyaan dan menjawab pertanyaan. Metode kedua yang digunakan adalah observasi, menurut Nawawi dan Martini (1991), adalah pengamatan dan pencatatan secara sistematik terhadap unsur-unsur yang tampak dalam suatu gejalan atau gejala-gejala dalam objek penelitian. Dalam melakukan pengumpulan data, penulis melakukan pengamatan dengan menghadiri pameran-pameran fotografi yang diadakan dibeberapa tempat seperti misalnya di Galeri Antara. Wawancara dilakukan dengan berbincang-bincang secara langsung dengan para fotografer baik pemula maupun professional yang telah lama bergelut dibidang fotografi. Sebagian data yang berhasil dikumpulkan didapat dari buku-buku yang membahas fotografi monokrom hitam putih pada khususnya. Selain itu ada data-data yang berhasil dikumpulkan penulis juga berasal dari artikel-artikel mengenai fotografi, khususnya fotografi monokrom hitam putih dari berbagai sumber media massa seperti majalah dan media elektronik, dan dari situs-situs yang khusus membahas fotografi di dunia maya.

Dalam penelitian ini, penulis menggunakan teori struktural atau biasa disebut saja dengan strukturalisme sebagai landasan. Strukturalisme adalah sebuah aliran pemikiran yang berpengaruh dalam khazanah pemikiran Barat. Dekade 60-an dianggap sebagai masa pergolakan intelektual dengan pesatnya perkembangan teori strukturalisme. Bersamaan dengan beberapa teori lain seperti eksistensialisme, dan madzhab kritis (aliran Frankfurt). Pada masa ini pula nama Herbert Marcuse (salah satu tokoh madzhab Frankfurt) menjadi semacam ikon pergerakan intelektual yang sedang naik daun saat itu. Tokoh inilah yang nantinya mengembangkan sayap teori struktural melalui pendekatan fungsionalisme struktural.

Struktualisme adalah bagian dari disiplin ilmuilmu sosial, yang perkembangannya diawali di Prancis melalui tokoh Ferdinand de Saussure. Saussure adalah ahli filsafat kebahasaan berkebangsaan Swiss (1857-1913). Pada pengantar ini teori struktural akan sedikit banyak memberikan gambaran pada strukturalisme linguistik dan sosiologis antropologis.

Saussure memahami bahwa bahasa mempunyai struktur dan peraturan-peraturannya yang sistematik (Charles E Bressler, 1999:89). Teori inilah yang mampu mengimbangi pemikiran Marxisme yang sedang menjadi trend pemikiran di Perancis pada saat itu. Istilah strukturalisme sendiri diperkenalkan pertamakali oleh Roman Jakobson seorang ahli linguistik Russia. Kajian kebahasaan sebelum Saussure, hanyalah berkutat pada kondisi linguistik semata, yakni pada bentuk aturan kebahasaan yang 
disepakati, seperti grammar, ilmu nahwu, ilmu sharaf, dan lain-lain.

Teori strukturalisme banyak digunakan untuk melakukan penelitian, kebanyakan untuk objek umum seperti kelompok masyarakat atau individu. Namun yang paling signifikan adalah penggunaannya untuk penelitian sastra. Dalam penelitian ini, teori strukturalisme difungsikan untuk mengurai berbagai hubungan atau relasi antar tanda yang tertuang dalam sebuah foto. Melalui pendekatan struktural, terdapat beberapa prinsip yang perlu diperhatikan; yang pertama adalah prinsip keseluruhan, yakni melihat hubungan antar struktur dalam sebuah foto secara keseluruhan, yang kedua adalah prinsip hubungan keterkaitan, yakni setiap satu struktur berkait dengan sturktur yang lain dalam sebuah foto yang sama, dimana makna dari sebuah objek hanya akan dapat didapatkan manakala berhubungan dengan struktur lain, yang ketiga adalah prinsip transformasi, dimana makna suatu objek dihasilkan dari adanya perubahan-perubahan struktur yang terjadi, yang keempat adalah prinsip regulasi diri, yaitu makna suatu objek dihasilkan dari objek itu sendiri beserta hubungannya dengan objek lain dalam sebuah foto, dan tidak dipengaruhi oleh fotografer, yang kelima adalah prinsip oposisi biner, yaitu dimana makna dihasilkan dari tanda-tanda yang saling beroposisi.

\section{KAJIAN LITERATUR}

Sejarah fotografi tidak lepas dari penemuan kamera dan media rekam yang berupa film. Proses pencahayaan film terjadi di dalam kamera dan direkam dalam media rekam berupa film tersebut. Fotografi berasal dari bahasa Yunani, yaitu phos yang berarti cahaya dan graphein yang berarti menggambar. Istilah fotografi pertama kali diperkenalkan oleh Sir John Herschel pada tahun 1893. Fotografi diartikan dengan menggambar dengan cahaya.

Kamera dari berbagai tipe telah dikenal selama beberapa abad. Salah satunya adalah kamera obscura yang dalam bahasa latin berarti 'ruang gelap'. Kamera obscura adalah sebuah kotak atau ruangan dengan sebuah lubang kecil dibagian tengah dari salah satu sisi dindingnya. Suasana atau pemandangan yang di luar kotak atau ruangan tersebut terlihat sebagai gambar yang terproyeksinya secara terbalik, atas dan bawah, kiri dan kanan, pada permukaan yang berlawanan dengan lubang kecil tersebut. Kamera obscura menjadi populer pada masa renaissance dan dianggap sebagai suatu keingintahuan yang menghibur.

Prinsip kerja yang diterapkan pada view camera modern yang pertama kali dibuat oleh Robert Boyle pada tahun 1670. Dengan menggunakan lembaran kertas yang tembus cahaya, pengguna kamera tersebut dapat mereka ulang gambar yang muncul dan mengabadikannya.
Penyempurnaan lebih lanjut pada tahun-tahun berikutnya melahirkan camera lucida, yang mirip dengan overhead projector yang digunakan hingga saat ini, dimana jika kita arahkan lensa yang ada pada overhead projector ke arah jendela dan meletakkan selembar kertas putih pada bagian kaca dimana transparansi biasa diletakkan, maka kita akan dapat melihat obyek atau pemandangan di luar jendela terproyeksikan ke permukaan ke permukaan kertas tersebut. Jenis kamera ini kemudian banyak digunakan oleh para turis yang mengunjungi suatu daerah dan ingin mengabadikan apa yang dilihatnya. Hasil yang didapatkan kemudian diwarnai dan disusun ke dalam album.

Pada awal abad 19, sebagian individu mulai mencari tahu bagiamana menggunakan kimia dengan tujuan untuk menangkap gambar tyang diproyeksikan oleh lensa kamera. Permasalahan tersebut kemudian dipecahkan secara terpisah oleh L. J. M. Daguerre dan Willianm Henry Fox Talbot pada tahun 1839. Foto diatas adalah foto dari Boulevard du Temple yang dihasilkan oleh Louis Daguerre pada tahun 1839. Foto tersebut adalah foto sebuah jalan yang ramai namun tampak sepi pada foto tersebut karena waktu pengambilan foto (eksposure) yang lama menyebabkan tidak tampaknya orang-orang yang beraktivitas di sekitar jalan tersebut.

Metode yang dikembangkan oleh Fox Talbot pada dasarnya sama dengan yang dikenal oleh masyarakat luas pada jaman modern. Proses tersebut dengan cepat menjadi lebih mudah dan dapat dilakukan oleh para fotografer baik amatir maupun profesional. Seiring dengan berjalannya waktu relatif singkat, studio fotografi bermunculan dan menyebar ke segala penjuru dunia. Perkembangan proses cetak berjalan sejajar dengan kemajuan dalam dunia fotografi dan pada tahun 1860 foto-foto yang dihasilkan oleh para fotografer mulai bermunculan dalam buku, majalah, dan surat kabar lalu munculah ungkapan "one picture is worth a thousand words".

Sejarah fotografi tidak lepas dari penemuan kamera dan media rekam berupa film tersebut. Fotografi berasal dari bahasa Yunani, yaitu phos yang berarti cahaya dan graphein yang berarti menggambar. Istilah fotografi pertama kali diperkenalkan oleh Sir John Herschel pada tahun 1839. Fotografi diartikan dengan menggambar dengan cahaya.

Kamera dari berbagai tipe telah dikenal selama beberapa abad. Salah satunya adalah kamera obscura yang dalam bahasa latin berarti 'ruang gelap'. Kamera obscura adalah sebuah kotak atau ruangan dengan sebuah lubang kecil dibagian tengah dari salah satu sisi dindingnya. Suasana atau pemandangan yang di luar kotak atau ruangan tersebut terlihat sebagai gambar yang terproyeksikan secara terbalik, atas dan bawah, kiri dan kanan, pada permukaan yang berlawanan dengan lubang kecil tersebut. Kamera obscura menjadi populer pada masa renaissance 
dan dianggap sebagai suatu keingintahuan yang menghibur.

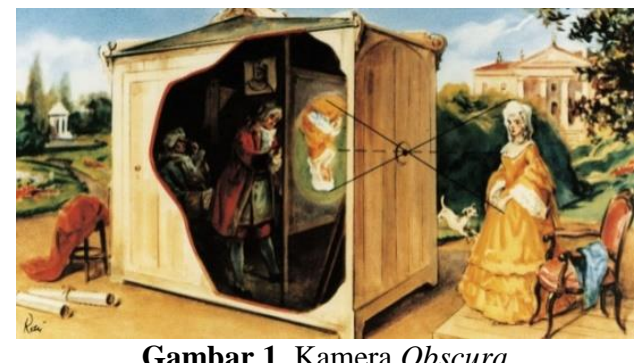

Prinsip kerja yang sama diterapkan pada view camera modern yang pertama kali dibuat oleh Robert Boyle pada tahun 1670. Dengan menggunakan lembaran kertas yang tembus cahaya, pengguna kamera tersebut dapat mereka ulang gambar yang yang muncul dan mengabadikannya.

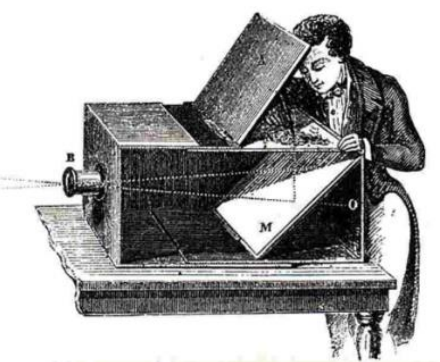

Gambar 2. Kamera Obscura

Penyempurnaan lebih lanjut pada tahuntahun berikutnya melahirkan camera lucida, yang mirip dengan overhead projector yang digunakan hingga saat ini, dimana jika kita arahkan lensa yang ada pada overhead projector ke arah jendela dan meletakkan selembar kertas putih pada bagian kaca dimana tranparansi biasa diletakkan, maka kita akan dapat melihat obyek atau pemandangan di luar jendela terproyeksikan ke permukaan kertas tersebut. Jenis kamera ini kemudian banyak digunakan oleh para turis yang mengunjungi suatu daerah dan ingin mengabadikan apa yang dilihatnya. Hasil yang didapatkan kemudian diwarnai dan disusun ke dalam album.

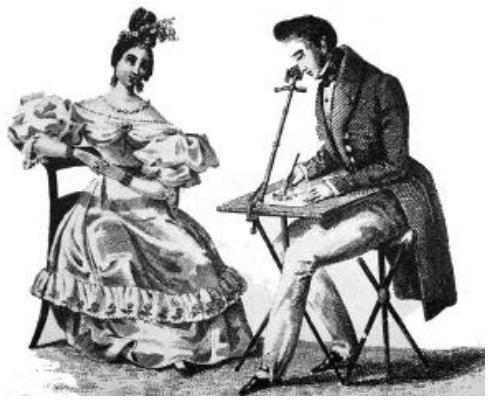

Gambar 3. Kamera Obscura

Pada awal abad 19, sebagian individu mulai mencari tahu bagaimana menggunakan kimia dengan tujuan untuk menangkap gambar yang diproyeksikan oleh lensa kamera. Permasalahan tersebut kemudian dipecahkan secara terpisah oleh L. J. M. Daguerre dan Willianm Henry Fox Talbot pada tahun 1839.

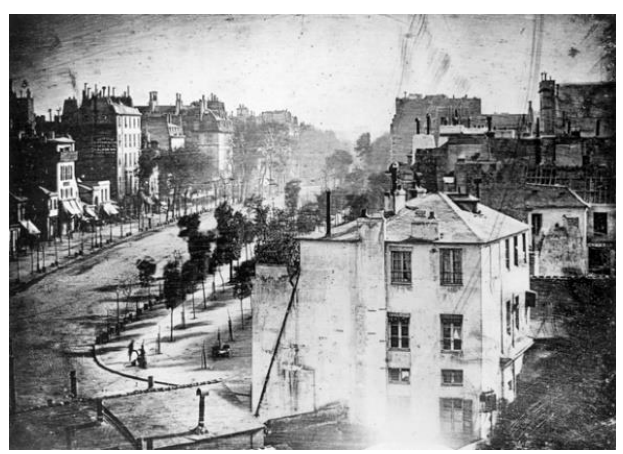

Gambar 4. Hasil foto pertama Obscura

Foto diatas adalah foto dari Boulevard $d u$ Temple yang dihasilkan oleh Louis Daguerre pada tahun 1839. Foto tersebut adalah foto sebuah jalan yang ramai namun tampak sepi pada foto tersebut karena waktu pengambilan foto (exposure) yang lama menyebabkan tidak tampaknya orang-orang yang beraktivitas di sekitar jalan tersebut.

Metode yang dikembangkan oleh Fox Talbot pada dasarnya sama dengan yang dikenal oleh masyarakat luas pada jaman modern. Proses tersebut dengan cepat menjadi lebih mudah dan dapat dilakukan oleh para fotografer baik amatir maupun professional. Seiring dengan berjalannya waktu dan semakin matangnya perkembangan teknik cetak, fotografi berkembang menjadi sebuah cara baru dalam berkomunikasi, dan dalam waktu relatif singkat, studio fotografi bermunculan dan menyebar ke segala penjuru dunia. Perkembangan proses cetak berjalan sejajar dengan kemajuan dalam dunia fotografi dan pada tahun 1860 foto-foto yang dihasilkan oleh para fotografer mulai bermunculan dalam buku, majalah, dan surat kabar. Dan munculah ungkapan "one picture is worth a thousand words".

\section{HASIL PENELITIAN DAN ANALISIS}

Ketidakhadiran warna dalam fotografi monokrom hitam putih tidak berarti hilang atau musnahnya warna itu sendiri. Fotografi monokrom hitam putih adalah sebuah pilihan, dan secara mengejutkan, pilihan ini dapat menarik perhatian dan memberikan lebih banyak warna ke dalam foto itu sendiri dibandingkan jika foto tersebut dihadirkan dalam format berwarna. Jika kita ingin berpikir dalam kerangka hitam putih, kita harus belajar melihat dunia sekitar kita seperti terlihat melalui kamera dalam kerangka warna yang tersirat dan gradasi warna abu-abu.

Sebuah foto hitam putih memiliki potensi untuk menghadirkan susunan gradasi dari hitam tanpa detail hingga putih tanpa detail. Hal ini jarang 
terlihat dalam foto berwarna pada umumnya, dimana putih tanpa detail diterjemahkan sebagai highlight blowout dan hitam tanpa detail diterjemahkan sebagai impenetrable shadow.

Berpikir dalam kerangka hitam putih sama artinya dengan berpikir ktentang kekontrasan. Objekobjek yang tampil dalam sebuah foto monokrom hitam putih adalah merupakan shape, desain dan bentuk yang hadir membentuk komposisi. Dalam dunia fotografi monokrom hitam putih, formalisme ini hadir secara konsisten.

Kontras adalah daerah atau gradasi diantara hitam dan putih. Dalam fotografi monokrom hitam putih, alat utama dalam menghadirkan komposisi yang baik adalah tepian, yaitu garis yang terbentuk antara bidang hitam dan bidang putih. Tepian yang tegas antara bagian yang terang dan bagian yang gelap akan diterjemahkan sebagai suatu bentuk warna hitam pada latar yang putih atau suatu bentuk berwarna putih pada latar yang hitam.

Saling keterkaitan antara hitam dan putih menghadirkan kompleksitas dalam visual ruang negative (negative space) dan ruang positif (positive space) dalam sebuah komposisi bidang. Seorang fotografer berpengalaman tahu bahwa menciptakan suatu elemen kedalam visual yang seringkali tidak muncul dalam sebuah foto dalam format berwarna. Dalam upaya menghadirkan kedalaman visual tersebut terdapat beberapa cara pandang yang perlu diperhatikan, yang pertama, bayangan yang kuat dan menarik, dimana bayangan itu sendiri dapat menghadirkan atau menciptakan garis tepian yang kuat antara gelap dan terang. Kedua, komposisi yang monoton, dengan tidak adanya warna maka seorang fotografer dapat menambahkan tingkat gelap-terang ataupun menambahkan efek-efek tertentu untuk menciptakan foto dengan tingkat kontras yang tinggi. Ketiga, kondisi ekkstrim antara daerah yang memiliki tingkat kecerahan yang tinggi dan bayangan dari suatu subjek dalam sebuah foto. Jika terdapat perbedaan anntara terang dan gelap yang ekstrim dalam sebuah komposisi foto, maka foto tersebut cocok untuk dijadikan foto monokrom hitam putih dengan kontras yang menunjang.

Jika subjek-subjek foto yang memiliki tingkat kontras yang tinggi telah didapat, terdapat beberapa hal lainnya yang sebaiknya diperhatikan dan mungkin perlu dilakukan, yaitu, pertama, memperhatikan komposisi foto secara keseluruhan untuk memperkuat kesan kedalaman visual yang akan dihasilkan, terutama terhadap subjek. Kedua, pergunakan pencahayaan tambahan untuk dapat menghasilkan tingkat kekontrasan yang maksimal. Ketiga, bagian yang gelap dapat dibuat underexpose sehingga terlihat hitam pekat dan bagian yang terang dapat dibuat overexpose sehingga terlihat putih tanpa detail untuk memperkuat kesan kedalaman yang diinginkan, sedangkan bagian yang membutuhkan lebih banyak detail dapat dikompensasikan dengan bantuan perangkat lunak. Keempat, menimbang beberapa efek yang dapat diterapkan dalam pemrosesan untuk meningkatkan rentang tonal, atau untuk memperkuat terang dan gelap pada bagian tertentu yang dianggap penting dalam komposisi.

Setiap orang memiliki harapan bahwa obyek apapun maupun pemandangan yang dilihatnya memiliki warna. Pada kenyataannya, setiap objek apapun yang dilihat dalam dunia monokro hitam putih akan dilihat dan dipersepsi memiliki warna, karena mereka yang melihatnya mengetahui fakta bahwa objek apapun yang dilihatnya memiliki warna. Manusia memiliki kecenderungan untuk mempersepsi foto monokrom hitam putih yang dilihatnya berwarna. Dengan pada itu, seorang fotografer yang menampilkan foto-foto karyanya dalam bentuk monokrom hitam putih dapat berasumsi bahwa subjek yang tampil dalam fotonya akan terlihat berwarna. Oleh karena itu, seorang fotografer dapat memanfaatkan apa yang dapat ditampilkan sebuah foto hitam putih dengan sangat baik, yaitu bentuk dan kontras. Dalam dunia fotografi monokrom hitam putih, warna akan muncul dan dipersepsikan oleh mereka yang melihatnya.

Terdapat beberapa hal yang perlu diperhatikan untuk dapat memanfaatkan secara maksimal warna yang tersurat dari sebuah foto monokrom hitam putih, yaitu, pertama, carilah subjek foto yang memiliki warna yang sudah diketahui secara luas, seperti misalnya buah apel atau jeruk. Kedua, pertimbangkan subjek yang memiliki warna alami yang kurang menarik, yang dapat tampil lebih menarik dalam format monokrom hitam putih sesuai dengan persepsi orang-orang yang melihatnya. Ketiga, mencoba menampilkan komposisi yang menarik dimana aspek formal dari desain lebih dititikberatkan dari kehadiran warna dalam foto tersebut.

Sebuah foto monokrom hitam putih menampilkan spektrum warna yang utuh dalam bentuk monokrom. Dengan tidak hadirnya warna dalam suatu foto monokromatik hitam putih, tercipta suasana atau nuansa ambigu dan misterius yang kuat dan jika foto tersebut dibuat dengan baik dan benar maka suasana ambigu yang tercipta akan membuat orang-orang yang melihatnya rela untuk membuang waktu lebih banyak dalam menikmati karya foto tersebut. Idealnya, ambiguitas visual harus diatur sedemikian rupa sehingga subjek utama yang ditampilkan akan dapat ditangkap oleh pemirsanya setelah mereka merasakan implikasi yang kuat dari tampilan foto tersebut secara keseluruhan. Sebuah foto monokrom hitam putih yang hadir dengan memanfaatkan implikasi visual yang kuat dapat membuat pemirsanya terkesima dan merasakan adanya hubungan yang dekat dengan sang fotografer dan dengan foto yang ditampilkan itu sendiri.

Untuk dapat menghadirkan foto dengan memanfaatkan abiguitas yang tercipta dan memiliki implikasi visual seperti yang diharapkan terdapat 
beberapa hal yang perlu diperhatikan, pertama, carilah subjek foto yang dapat intepretasikan atau diartikan secara visual dalam lebih dari satu cara. Kedua, pergunakan pengaturan posisi, framing, focus dan exsposure untuk mengeksporasi abiguitas visual yang mungkin dihasilkan dengan memberikan sedikit penekanan pada arti lain yang dapat dihadirkan secara visual. Ketiga, sudut pengambilan foto terhadap subjek, pemilihan jenis lensa yang dipergunakan berperan penting dalam menciptakan foto yang memiliki ambiguitas visual seperti yang diharapkan. Keempat, berusaha untuk menciptakan foto yang memiliki arti visual yang hanya dapat ditangkap dan dimengerti secara bertahap, sedikit demi sedikit.

Menghasilkan foto hitam putih digtal bagi sebagian orang merupakan pekerjaan yang sulit diterima dan dianggap hanya berdasar pada hasrat artistik semata, mengingat bahwa gambar yang direkam oleh kamera sebagai alat yang dipergunakan pada kenyataan penuh warna. Dengan kata lain, memotret dalam dunia digital adalah menangkap sinar yang penuh warna dan memprosesnya dalam rentang gradasi abu-abu. Adlah penting untuk dimengerti bahwa warna yang ditangkap oleh kamera digital dapat digunakan secara positif sebagai dasar dalam transformasi ke dalam rentang monokrom hitam putih.

Terdapat banyak cara yang dapat ditempuh untuk dapat menghasilkan foto monokrom hitam putih dalam dunia fotografi digital. Semakain besar upaya yang dilakukan akan cenderung menghasilkan hasil foto yang semakin baik pula. Terdapat banyak Teknik yang dapat dilakukan untuk mengkkonversi hasil foto digital berwarna ke dalam format monokrom hitam putih, mulai dari Teknik yang sederhana sampai teknik yang rumit yang dapat dilakukan dengan bantuan perangkat lunak pengolah gambar yang ada. Berikut adalah tingkatan pengolahan gambar mulai dari yang paling mudah hingga yang sulit sesuai dengan hasil yang didapat:

1. Konversi data JPEG langsung di kamera.

2. Konversi data JPEG menjadi monokrom hitam putih dengan bantuan perangkat lunak sederhana seperti misalnya iPhoto, Picassa, Flickr, Photoshop Elements dan lain sebagainya.

3. Konversi data RAW menjadi monokrom hitam putih dengan bantuan perangkat lunak Adobe Camera RAW (ACR).
4. Data RAW dari kamera diolah dengan bantuan perangkat lunak Adobe Lightroom dalam format berwarna dan kemudian dikonversikan dengan bantuan perangkat lunak yang sama kedalam format monokrom hitam putih.

5. Data RAW dari kamera diolah dalam format berwarna dengan bantuan perangkat lunak Adobe Lightroom dan Photoshop atau Adobe Camera RAW (ACR) dan Photoshop kemudian dikonversikan dalam format monokrom hitam putih. Jika dilakukan dengan baik, teknik pengolahan foto ini akan menghasilkan foto monokrom hitam putih yang sangat baik.

Visualisasi dari fotografi monokromatik hitam putih adalah menangkap dan berbicara melalui foto tanpa kehadiran warna dengan mengandalkan visualisasi kedalaman dan kontras secara kuat dan jernih. Implikasi visual yang kuat dalam penyampaian pesan melalui fotografi monokrom hitam putih dapat menghadirkan citra yang menggugah secara emosional, terlepas dari media rekam yang digunakan. Dalam dunia fotografi digital modern terdapat banyak kemudahan, baik dalam bentuk perangkat keras maupun dari perangkat lunak, yang terus berkembang sejalan dengan perkembangan teknologi, yang jika dimanfaatkan dengan baik akan menghasilkan implikasi visual yang luar biasa.

\section{DAFTAR PUSTAKA}

Schafer, John P. (2010). The Ansel Adams Guide: Book 1: Basic Techniques of Photography. New York: Litle, Brown and Company.

Schafer, John P. (2010). The Ansel Adams Guide: Book 2: Basic Techniques of Photography. New York: Litle, Brown and Company.

Davis, Harold. (2010). Creative Black \& White: Digital Photography Tips \& Techniques. Indianapolis, Indiana: Wiley Publishing.

Barthes, Roland. 2000. Camera Lucida: Reflection on Photography. London: Vintage Book.

Davenport, Alma. 1992. The History of Photography: An Overview. Boston: Focal Press.

Hacking, Juliet. 2012. Photography: The Whole Story. London: Thames \& Hudson.

Prosser, Jon. 2006. Image-based Research: A Sourcebook for Qualitative Researchers. London and New York: Routledge Falmer. 